\title{
Molluscum contagiosum on tattoo
}

\author{
Molusco contagioso em tatuagem
}

Luciana Molina $^{1}$

Ricardo Romiti $^{2}$

\begin{abstract}
Molluscum contagiosum is a disease caused by a poxvirus characterized by benign self-limited eruption of single or multiple cutaneous spherical and pearly papules. Transmission usually occurs by direct contact with infected hosts. It is reported the case of a 22-year-old Caucasian male who presented characteristic pearly and umbilicated papules strictly located on the region of a tattoo. Histopathologic exam confirmed the diagnosis of molluscum contagiosum. The authors describe an uncommomn manifestation of dissemination of this virus in tattoos and also present a literature review emphasizing the transmission pathways and treatment of Molluscum contagiosum.

Keywords: Molluscum Contagiosum; Poxviridae Infections; Tattoo

Resumo: Molusco contagioso é uma dermatovirose causada por poxvírus e caracterizada por erupção benigna e autolimitada de uma ou múltiplas pápulas esféricas e brilhantes. A transmissão habitualmente ocorre por contato direto com indivíduos infectados. Relata-se caso de doente masculino, 22 anos, com história de surgimento de numerosas pápulas umbilicadas localizadas estritamente sobre a região de uma tatuagem. Exame histopatológico de uma das pápulas confirmou a hipótese clínica de molusco contagioso. Os autores descrevem uma manifestação pouco frequente da disseminação desse vírus em tatuagens e apresentam uma revisão da literatura, enfatizando as vias de transmissão e a terapêutica do molusco contagioso. Palavras-chave: Infecções por Poxviridae; Molusco contagioso; Tatuagem
\end{abstract}

\section{INTRODUCTION}

The family of poxvirus consists of a comprehensive group of DNA-virus of high molecular weight. It is responsible for diseases that vary from serious and often fatal forms such as smallpox to self limited and localized infections such ectyma and Molluscum contagiosum. ${ }^{1}$

Molluscum contagiosum is notable for representing the most frequent condition of this group. It presents universal distribution being more frequent in school children. As for adults, it primarily affects the anogenital region through sexual transmission. Disseminated forms, atypical or giant, not rarely affect immunosuppressed patients. ${ }^{2,3}$ Incubation period varies and individual lesions tend to recede in two or three months. Complete regression of the condition in children tends to occur in up to three years.

Inoculation occurs after direct contact with other affected individuals mainly among brother/sisters and classmates. We emphasize the increasing incidence associated with the use of swimming pools in communities. It usually occurs as a sexually transmit- ted disease in adults.

The authors report the case of a immunocompetent patient evolving with disseminated Molluscum contagiosum condition restricted to the area of tattoo which had been done seven before.

\section{CASE REPORT}

Caucasian male patient, aged 22 referred to the emergence, for about two months, of numerous papules strictly localized on the region of a tattoo. The tattoo had been done seven months before on his back. The tattoo had been done by a professional tattooist, using black pigment, in various sessions, within a total period of four months. About four weeks after the completion of the tattoo the patient noticed the emergence of small bright papules on the site of the tattoo. Lesions were asymptomatic and, according to the patient, they had been progressively increasing during the last months. The patient denied relevant personal or family history and also affirmed that he was not using any medication.

Received on 11.11.2009.

Approved by the Advisory Board and accepted for publication on 05.05.10

* Study conducted in a private office.

Conflict of interest: None / Suporte financeiro: Nenbum

Financial funding: None / Conlito de interesse: Nenbum

Medical doctor, dermatologist- São Paulo (SP), Brazil

Medical doctor, Assistant- Department of Dermatology of the University Hospital from the University of São Paulo (USP) - São Paulo (SP), Brazil

(C)2011 by Anais Brasileiros de Dermatologia 
Dermatological examination of the back showed the presence of around 50 papules, with smooth surface and pearly-white color, most with central umbilication, measuring from two to four centimetres in diameter. Lesions were irregularly distributed on the tattoo, on the back of the patient. (Pictures 1 and 2). Similar lesions were not found on other skin and mucosal areas.

Anatomopathological examination obtained from biopsy material of samples of the back of the patient extracted by curettage showed the presence of large viral inclusion bodies within the cytoplasm of cells, moving the nucleus to the periphery. (Picture 3).

Serologies for hepatitis B and C, HIV and syphilis were negative. New serologies will be carried out due to the possibility of window period in the case of acquisition of other infection during the process of making the tattoo. the lesions.

Treatment was carried out through curettage of

\section{DISCUSSION}

The clinical lesion of Molluscum contagiosum is characterized by bright and semi-spherical papule usually distinctly umbilicated or with slight central depression, of a few millimeters in diameter. It affects the skin and exceptionally the mucosae. It can be observed, in atopic Molluscum contagiosium, eczema development area around the area of the lesions named eczema molluscatum. The lesions, in immunosupressed patients, tend to be disseminated and can take large dimensions.

The dermatological condition of Molluscum contagiosum is generally quite typical and does not present difficulties for diagnosis. Clinical variants such as giant molluscum and follicular variants can

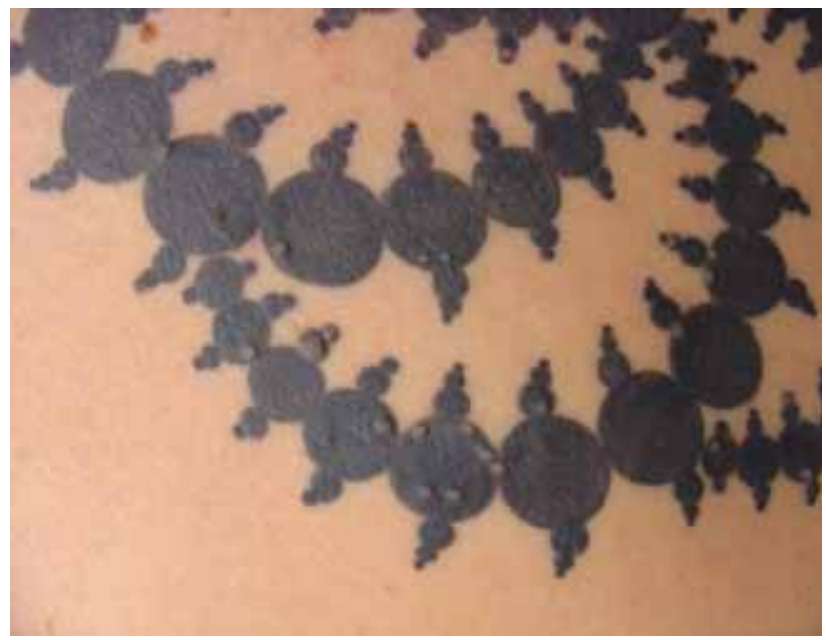

Figure 1: Papules with smooth surface and pearly-white color located on tattoo

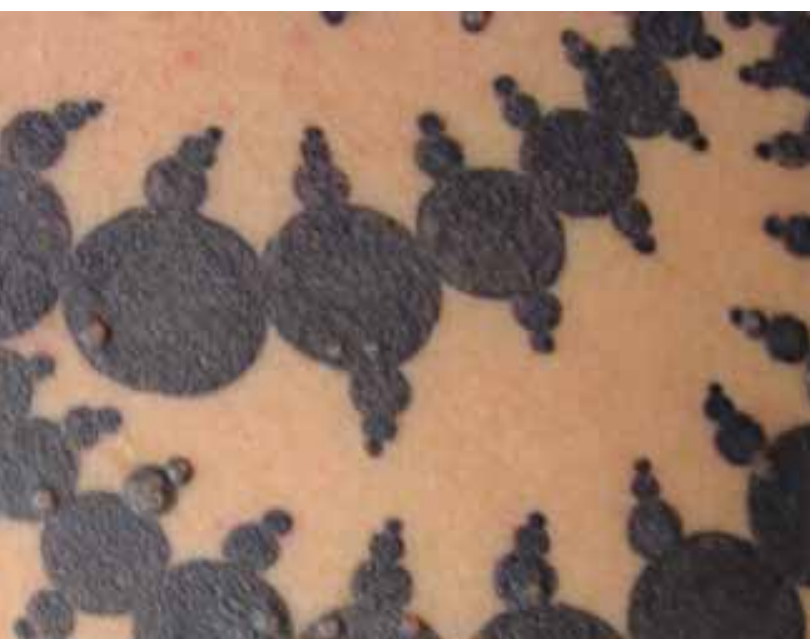

FIGURE 2: Some umbilicated papules located on tattoo

make diagnosis more difficult. When indicated, the histopathological examination is quite typical, with viral eosinophilic material (Henderson-Patterson corpuscles) occupying the cytoplasm and moving the nucleus of keratinocytes to the periphery. Epidermis grows into the dermis forming multiple lobes many times closely aggregated. ${ }^{4}$ Profile study of the cytokeratins in lesions of molluscum contagious showed alterations in the differenciation of the keratinocytes, evidenced by the presence of cytokeratin K14 and expression of p63 in supra-basal and spinous layer as well as early expression of involucrin and filaggrin. The hyperproliferative state of the epidermis triggered by infection can be confirmed by the presence of cytokeratin $\mathrm{K} 16 .^{5}$

Elective treatment of molluscum contagious is

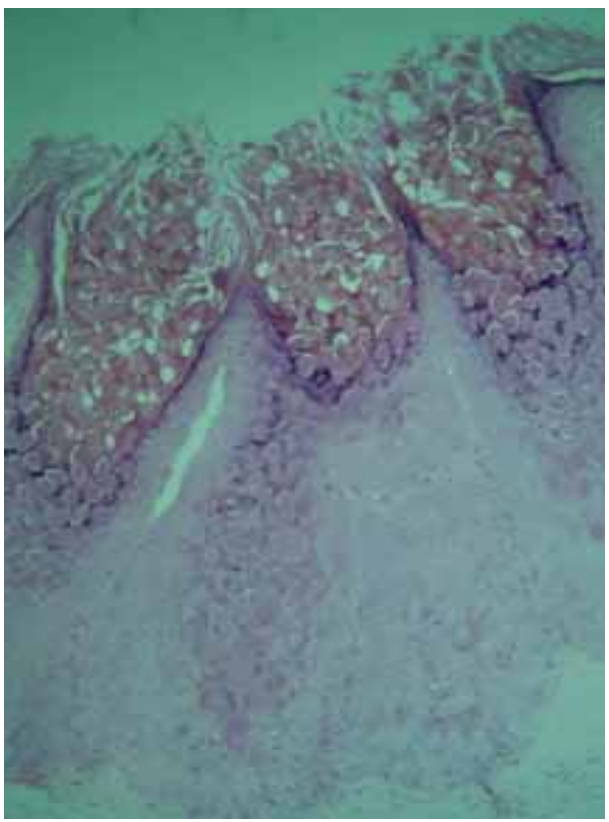

Figure 3:

Histopathologi c section showing the presence of large viral inclusion bodies within the cytoplasm of cells 
curettage of all lesions. In children the procedure can be done under local anesthesia with lidocaine-prilocaine, applied previously for one to two hours on each lesion. ${ }^{6}$ Regression usually occurs without scarring.

When there are numerous and disseminated lesions therapeutics may involve the use of liquid nitrogen, in surgery, or still the application of topical medication such as podophyllotoxin or retinoic acid. The use of intradermal injections of Candida antigen has been reported with variable results. ${ }^{7}$ More recently we have demonstrated the efficacy and safety profile of the use of potassium hydroxide (KOH) 5 to $10 \%$ in aqueous solution, in the treatment of molluscum contagious in immunocompetent children. ${ }^{8-10}$ The solution must be applied at home by the patient or parents through the use of a swab on each lesion. The applications should be repeated daily until there are signs of erythema or local edema. At this moment, the treatment should be stopped to avoid local irritation. The lesions that have not receded after the first sessions of the treatment are suceptible to new serial treatments until there is complete regression of the condition. The use of $\mathrm{KOH}$ offers a safe alternative, extremely effective and of low cost for the management of molluscum contagious

Although any infection can be theoretically accidentally inoculated by tattoing, in practice, the most frequently observed are syphilis, tuberculosis, hepatitis and viral warts. ${ }^{11}$ As for molluscum contagious, there are few cases in the medical literature reporting the spread of the lesions in tattoos. Foulds ${ }^{12}$ reported in 1982 the first case of a male patient, aged 20, immunocompetent that had presented seven lesions on a mulitcolored tattoo three months after its end. The umbilicated papules were localized only over the black coloration. The author suggested that the inoculation of the virus had probably occured through the ink. The second case was reported by Salmaso and cols $^{13}$ in 2001and it referred to a young female patient, aged 20,immunocompetent, that had presented 10 lesions over a black tattoo that had been done three weeks before. Perez ${ }^{11}$ and cols, in 2006, described the third case of molluscum contagious over tattoo of brown-grayish pigment, five months after the end of the procedure in a young male immunocompetent patient, aged 20 .Up to now, in the last three years, three more cases have been reported, all of them in male immunocompetent patients. ${ }^{14-16}$ There are at least two hypothesis to explain the pathogenesis of the lesions of molluscum contagious on tattoos: the viruses being transmitted through instruments used for tattoing, or inks being contaminated by the viruses. Besides that, some authors suggest that the black pigment can decrease, locally, humoral and cellular immunity. ${ }^{17}$

We have reported here a case of molluscum contagious accidentaly innoculated in area of tattoing. This relatively frequent skin virosis should be included in the differential diagnosis of infections occurring in the area of tattooing.

\section{REFERENCES}

1. Hanson D, Diven DG. Molluscum contagiosum. Dermatol Online J. 2003:9:2

2. Gur I. The epidemiology of Molluscum contagiosum in HIV-seropositive patients: a unique entity or insignificant finding? The epidemiology of Molluscum contagiosum in HIV-seropositive patients: a unique entity or insignificant finding? Int J STD AIDS. 2008;19:503-6.

3. Porro AM, Yoshioka MCN. Manifestações dermatológicas da infecção por HIV. An Bras Dermatol. 2000;75:665-691.

4. Mckee PH, Calonje E, Granter SR. Pathology of the skin with clinical correlations. $3^{\text {rd }}$ ed. London: Elsevier, Mosby; 2005. p. 1030-3.

5. Callegaro CF. Expressão de citoqueratinas, filagrina, involucrina, E-caderina e p63 em lesões de molusco contagioso [Tese]. São Paulo: Faculdade de Medicina da Universidade de São Paulo; 2008.

6. Jones S, Kress D. Treatment of molluscum contagiosum and herpes simplex virus cutaneous infections. Cutis. 2007:79(4 Suppl):11-7.

7. Maronn M, Salm C, Lyon V, Galbraith S. One-year experience with candida antigen immunotherapy for warts and molluscum. Pediatr Dermatol. 2008;25:189-92.

8. Romiti R, Ribeiro AP, Grinblat BM, Rivitti EA, Romiti N. Treatment of molluscum contagiosum with potassium hydroxide: a clinical approach in 35 children. Pediatr Dermatol. 1999;16:228-231.

9. Romiti R, Ribeiro AP, Romiti N. Evaluation of the effectiveness of $5 \%$ potassium hydroxide for the treatment of molluscum contagiosum. Pediatr Dermatol. 2000;17:495.

10. Short KA, Fuller LC, Higgins EM. Double-blind, randomized, placebo-controlled tria of the use of topical $10 \%$ potassium hydroxide solution in the treatment of molluscum contagiosum. Pediatr Dermatol. 2006;23:279-81.
11. Pérez Gala S, Alonso Pérez A, Ríos Buceta L, Aragüés Montañés M, Garcia Díez A. Molluscum contagiosum on a multicoloured tattoo. J Eur Acad Dermatol Venereol. 2006;20:221-2.

12. Foulds IS. Molluscum contagiosum: an unusual complication of tattooing. Br Med J 1982; 285: 607.

13. Salmaso F, Gnecchi L, Gianotti R, Veraldi S. Molluscum contagiosum on a tattoo. Acta Derm Venereol. 2001;81:146-147.

14. Pérez-Barrio S, González-Hermosa MR, Ratón JA, Díaz-Pérez JL. Moluscum contagiosum over a tattoo. Actas Dermosifiliogr. 2009;100:152-4.

15. Panasiti V, Devirgiliis V, Roberti V, Curzio M, Calvieri S. Molluscum contagiosum on a tattoo: usefulness of dermoscopy. Int J Dermatol. 2008:47:1318-9.

16. Kluger N, Comte C, Guillot B. Molluscum contagiosum on a tattoo. Ann Dermatol Venereol. 2007;134(5 Pt 1):506-7.

17. Miller DM, Brodell RT. Verruca restricted to the areas of black dye within a tattoo. Arch Dermatol. 1994;130:1453-4.

MAILING ADDRESS / ENDEREÇO PARA CORRESPONDÊNCIA:

Luciana Molina

Rua Turiassu, 127 nono andar

05005001 Perdizes São Paulo-SP, Brazil

Telefone: 11-3662 4869

e-mail: lumolina35@botmail.com

How to cite this article/Como citar este artigo: Molina L, Romiti R. Molluscum contagiosum on tattoo. An Bras Dermatol. 2011;86(2):352-4. 